\title{
Research on the Innovative Development Path of College English Education under the New Situation
}

\author{
Sun Li \\ Department of Foreign Languages, Hubei University of Technology Engineering and Technology College, \\ Wuhan, Hubei, China, 430068
}

Keywords: new situation; College English; innovation

\begin{abstract}
English teaching in colleges and universities has been lasted for decades in China. However, in the course of College English teaching, it is not difficult to find that the vast majority of students are resting on their laurels of high school. The effect of College English teaching has little improvement on the student capability, due to the lack of teaching theories, as well as the lack of English practice skills resulting from the over-pursuit of writing. With the ever-increasing frequency of foreign economic and trade exchanges and cooperation, practical English skills have become a practical bottleneck problem for college graduates in China. In order to meet the requirements of English education at the present stage, it is necessary to innovate the traditional mode of thinking teaching, build a new relationship between teachers and students, optimize and integrate the content of English teaching, so as to improve the students' enthusiasm for English learning.
\end{abstract}

\section{Introduction}

As an important channel to cultivate English professionals, colleges and universities play an irreplaceable role in improving the number and quality of English professionals. The rise of new media has brought precious opportunities for the reform and innovation of college English education [1]. How to use the advantages of resources in the new media environment to reform and innovate English teaching concepts, modes, and means in colleges and universities is a question that must be considered for each university. The idea of innovation is in a pivotal position. The timely rise of new media has provided strong support for the concept of innovation. This new situation has also brought a tremendous impact on education. In the process of reforming and innovating English teaching in colleges and universities, it is only by introducing multimedia means more fully that the faculty can more freely integrate the awareness of reform and innovation into the process of teaching practice. Only in this way, the reform and innovation of English Teaching in Colleges and universities in China can be carried out more smoothly.

\section{The Status Quo of College English Education}

\subsection{Lack of practicality}

The traditional English teaching in Chinese colleges and universities is of the same origin and rarely changed, which has led to decades of stagnant English teaching [2]. Traditional English teaching not only has gradually become more and more rigid in teaching theory, but also has become obsolete and outdated in teaching methods. It has severely deviated from the rapidly developing social reality and the ever-evolving needs of the international community. The lack of practicality of the traditional English teaching theory is a common problem in the study of college English teaching theory in China. Because there is a vacuum zone between the theoretical research and the final implementation path, there is a serious disconnect between the theoretical research and the practical application of foreign languages, which led to the study of English theories appeared in the commonly known as non- practical. This aspect shows that previous research on English teaching theory has entered the stage of misunderstanding in castles in the air. On the other hand, it also shows 
that our country lacks more professional successors in English teaching and research.

\subsection{Excessive pursuit of writing}

College English Teaching in China is not only lack of theoretical practice, but also the problem of excessive pursuit of writing, which inevitably makes the teaching and final practical skills of college English teaching, as well as students' actual language adaptability and communication skills greatly reduced. Over emphasis on students' English reading ability and written grammar ability leads to a significant weakening of students' practical English proficiency. There is a serious problem of excessive pursuit of writing in the teaching of colleges and universities in China. Some of the problems have far exceeded the practical application category of English, which has caused that for those should not be weakened are excessively weakened, and those that do not need to be strengthened have been overstretched.

\subsection{Copying foreign English teaching methods.}

As a problem in College English Teaching in China, the copy of foreign English teaching methods in the light of the problems of traditional teaching methods is serious. Indeed, purely from a theoretical point of view, it is correct to follow the advanced teaching methods of developed countries. However, it is undeniable that developed countries have their own national conditions, as well as the status of students and basic knowledge in developed countries, and the learning status of students are very different from the students in China [3]. Regardless of the differences mentioned above, it is bound to make our students feel at a loss in the face of unexpected teaching methods. In addition, it should be clear that college English learning should pay more attention to language thinking process and expression output. In the process of international communication and application of English, the two most important inputs, conversation and writing, are far more important and more practical than writing skills.

\section{Research on Development of College English Teaching}

\subsection{Active training task teaching.}

The traditional type of college English teaching is mainly based on one-way indoctrination. This type of indoctrination is mechanically monotonous, resulting in relatively poor transfer between teachers and students. In the new situation, the acquisition of knowledge is more flexible, and the provision and search of information are also multidirectional, the acquisition of basic knowledge in teaching become within reach. Under such circumstances, traditional indoctrination teaching has completely behind the times, and thus many colleges and universities in our country have begun the teaching reform of the active training task. The reform of the active training task based on the new media is particularly suitable for practical courses. In English teaching, it has the self-evident advantage.

\subsection{Interactive task teaching.}

The experience and lessons accumulated during the past decades of teaching English taught us that one-sided, spoon-feeding teaching methods must be changed. At the same time, with the develop of sociaty, one-way feeding methods are also inevitably change. Different from the active training task teaching reform, interactive interactive task teaching reform provides students with a similar level of progressive English learning in the game. Each well-designed checkpoint test is proposed for practical skills improvement in English. In the interactive test process, the teacher side consists of at least three teachers who form an interaction group to communicate with students on indoor scenes and organize students to conduct outdoor business negotiations. Through continuous interaction with necessary instructions and guidance, the students' experience and skills gained in this process are far more profound and solid than the one-way teaching. 


\subsection{Socialization of virtual task teaching.}

The socialization process is a necessary process for every university student. What we learn and think in the university must accept the test of social melting pot. The social nature of the new media environment has begun to emerge at the beginning of the Internet, and the initial socialized application is a socialized communication based on the way of web pages or instant chat tools. This socialized communication has also brought new ideas for the reform of English teaching. For the improvement of language learning, learning in a virtual social environment is much more efficient than learning books over and over again. The scene of this virtual social reality can be created by the school in the campus network, and can also visit foreign university chat rooms, and carry out face-to-face English language communication with foreign students on the spot. At the beginning of every communication, teachers can arrange and communicate with the students for the purpose of communication. Under the impetus of the social virtual task, the students can get the baptism of the language in the social environment.

\section{Research on Innovation of College English Teaching}

\subsection{Optimize teaching resources.}

In college English teaching, traditional teaching methods cannot be used blindly, otherwise it will lead to student fatigue. English teaching in colleges and universities should pay attention to students' thinking activities so that they have the ability to study independently. To improve teaching quality, it must optimize teaching resources. This is what teachers need to do well. In the course of preparing lessons, it must build a complete knowledge point, combine the book knowledge, network resources, video resources, etc., optimize teaching methods, and combine with excellent teaching resources to further improve the level of college English teaching.

\subsection{Extend teaching content.}

As we all know, the optimization and extension of teaching content is the most important thing in English teaching reform and innovation. Constantly optimized teaching content and continuously extending teaching resources help make the quality of college English professional training significantly improved [4]. Under the new situation, new media technologies could be used to extensively collect, select, and apply teaching materials other than textbooks to extend the content of English teaching. So as to increase classroom information capacity, stimulate students' interest in learning, and activate English classroom atmosphere, and enhance students' learning effectiveness.

\subsection{Apply situational approach.}

English is very practical. In the context of economic globalization, it is an important communication tool for people to conduct business activities. English courses can develop students' language skills and professional skills in international exchanges and international trade. In view of the characteristics of English disciplines, the direction of English language curriculum reform in the new situation should emphasize the combination of language and practice. Using situational teaching methods, borrowing network multimedia to create business activity situations, and comprehensively using international trade, marketing and other aspects of knowledge, making corresponding multimedia courseware, allowing students to perform language learning in a simulated situation, both inspiring students' interest in learning and cultivating students' competence to deal with problems and language skills.

\subsection{Innovate English teaching model.}

The English curriculum reform should first change the traditional teaching philosophy, absorb the quintessence, and resist its dark side. It should also pay attention to cultivating the student's self-learning awareness, encourage students to set up study groups, guide students to use the time outside the classroom, use the network to collect information, and carry out problems and solutions, 
results exchanges, teacher-student interactions on the class forum, which allow students to study independently in a free and easy network environment.

\subsection{Apply information technology.}

To achieve the innovation of teaching methods, we should follow the student centered teaching mode and create a positive learning environment for students. Teachers should set up an innovative teaching consciousness, carry out the innovation of their own teaching ideas, do a good job in the promotion of information technology, carry out the equipment of the perfect teaching facilities, and meet the needs of the campus information construction at the present stage.

\section{Summary}

There are still many problems in English Teaching in Colleges and universities in China. Excessive writing has changed the language skills into the study of linguistics, which greatly weakened the practical skills needed in the process of international communication. The new environment has brought new opportunities for the reform and innovation of the diversified English teaching. It has changed the passive instillation into active exploration, the imparting of the single direction to the two-way interaction. Under the new situation, the reform and innovation of the English education will bring college students with the real experience and the practical skills of the language.

\section{References}

[1] He Jing, Liu Yan, Ge Zhongqiang. New media and college English teaching[j]. Modern Business Industry, 2014, 26(20), p.188

[2] Wang Hua, Zou Shixiang. Educational innovation from the perspective of new media[J]. Science and Technology of Chinese Universities, 2013(3), p.17

[3] Cao Fei. Explore the innovative way of College English teaching[J]. Journal of Jilin Education College, 2015, (10), p.93

[4] Xi Xiaodan. Practice and analysis of college business English teaching reform under the network environment[J]. Heihe Journal, 2013, (7), p.116 